\title{
Selected social phenomena following the extraction of mineral resources
}

\author{
Paweł Kocoń \\ Department of Public Management and Social Sciences, University of Economics in Katowice, 1 Maja Str. 47, 40-287 \\ Katowice, Poland \\ E-mail address: pawel.kocon@ue.edu.pl
}

\begin{abstract}
The author, due to the didactic needs and seeing a small gap in the way of presenting scientific data on the area of social science, have decided to present this work hoping that it will influence on widening both the social science and geography knowledge of the recipients, having connected the development and creation of certain social phenomena with particular economic activity, that is, the extraction of mineral resources. The aim of the hereby text is to present such social phenomena like organizational culture, discourse and social capital. The notions mentioned above ought to concern not only students, but also the specialists and scientists dealing with any of those two fields, as it seems prudent to follow the path of closely connecting two major issues emerging from two distinctively separate areas of science if that may help to better understand how such mixture influence people's behaviour and allows to draw conclusion on the effect such actions may have on community or society. Moreover, such fact was prior for the author to decide to work on the problem of protests for mining in the future. On the other hand, the article may help in organizing the process of exploitation of mineral resources in the different organizations involved in this type of activity.
\end{abstract}

KEY WORDS: organization culture, discourse, social memory, social capital

\section{Introduction}

The matter of the impact of social phenomena such as the identity, culture, rituals and social capital, understood as ,the amount of current and potential assets which an individual or a group deserves due to owning constant, more or less institutionalized network of relations, contacts, mutual recognition" (BOURDIEU \& WACQUANT, 2001, p. 104-105): and discourse on the example of exploitation of mineral deposits is described in this article. The phenomenon of moral panic concerns the issue of making a group of people feeling threatened by the reaction of the media exaggerating the events seen as a social problem. Mineral resources are the activity which is especially exposed on the negative social phenomena due to the often misunderstood impact on the environment and on the local community. Extraction of mineral resources is often contested because of the exaggerated or completely false damage, but on the other hand, it is desirable for economic reasons (MATCZAK, 1996; BADERA, 2014; BADERA \& KOCOŃ, 2014).
All of this results in measurable material losses for companies involved in the extraction of raw materials, which must abandon the exploitation of the lodes despite, for example, meeting rigorous environmental standards. The communities also lose, showing on the one hand their susceptibility to manipulation by the media and, on the other hand, wasting the possibility for the potential gains and tax concessions (BADERA \& KOCOŃ, 2015).

Nonetheless, a variety of social phenomena are constituted by the organizations involved in the extraction of mineral resources. The exploitation of lodes itself is often used as a "founding act" of the creation of local community and it causes its specific culture. Exploitation of mineral lodes also integrates community focused around the plant mining interests.

\section{Social phenomena and extraction of mineral resources}

The first and primary kind of phenomenon is the individual, regional and organizational identity. To simplify the matter, the identity is the answer, 
given by an individual person or group, to the question "Who am I/Who are we". It is also used in the anthropological, sociological and psychological studies, as well as in everyday language and journalism (see e.g. "Silesian identity") (WóDZ, 1993; WóDź \& Wódź, 2004). The identity can be associated with a profession, where strong identities are produced by occupations related to the exploitation of mineral resources. Professional identity of coal and salt miner or prospector strongly influenced on the continuation of mineral lodes and social shape of the region, in which this operation took place (NAWROCKI, 2006).

The organizational culture is lower level of social life than the regional identity. BRATNICKI ET AL. (1988) describe organizational culture as sharing the meanings and symbols, rituals and cognitive patterns, constantly formed and transformed as the organization is trying to balance the requirements to preserve the internal cohesion of the response needs detected in the environment (KOSTERA, 1996).

SCHEIN (1992) says that - "culture is the complex of the fundamental assumptions that a given group has invented, discovered or developed, learning to solve problems of adaptation to the environment and internal integration" (KoźMIŃSKI \& PIOTROWSKI, 1995, p. 302). Organizational culture is the "glue" of every organization. The specificity of mineral extraction, especially deep-sea mining coal or salt or copper, creates a strong bond between people working in this way. This relationship is reflected in the political and economic decisions regarding the cutting off or transfer of mining. For example, closing the mine in Kazimierz Górniczy, the district of Sosnowiec city, activated local community in expressing its objection to this decision (www 8).

An integral part of the organizational culture, especially that one which is strongly manifested in the organization, are rituals. SCHECHNER (2000, p. 221) writes that rituals are being explored as:

1) product of the evolutionary development of animals,

2) the structures of a specific form and definable relations,

3) symbolic meanings systems,

4) performative actions or processes,

5) experiences.

The ritual is a "collective behavior, perceived by the members of the given culture as socially necessary, although it plays only the role of an act, not having a direct impact on achieving objectives" (HofstedE, 2000, p. 337). Currently, the rituals in the mining culture are mainly connected with the feast of St. Barbara. Beer tavern or a "jump over the skin" are integral parts of the mining culture and therefore, of the process of exploitation of mineral resources (not just only the coal). It is similar in case of salt mining, where, especially in "Wieliczka" mine, mininig traditions are cultivated (www 2), or in copper mining (www 5).

Rituals play an important role in highlighting the organizational culture of the institution. Firstly, they show ceremonial values - by highlighting them during the momentous occasion. Secondly, rituals also determine the type of organizational culture by highlighting the company's main value.

The ex ample of such ritual is accepting new miners during mining feast. During the feast mining songs are sung, experienced miners are rewarded and new miners are accepted into the group according to certain ritual. First, newcomers swear to oath, then perform so called "jump over the skin", held by two seniors of mining group, then they are symbolically hit in the arm with a mining spade. After such ceremony, young miners are fully accepted in the mining community. During beer tavern, miners are obligatory dressed in mining uniform (www 4).

Rituals are part of a wider phenomenon that goes beyond the organization. This phenomenon is the discourse. According to VAN DIJK (2001, p. 9): "the concept of discourse cannot be limited to within one definition. This is undefined category". However, Van Dijk writes that "they are taking (researchers of discourse pm. PK) that discourse is a form of language use" (VAN DIJK, 2001, p. 10). The same author claims that a "definition describing (...) functional aspects should be the one that defines discourse as a communication event" (VAN DIJK, 2001, p. 10).

Nijałkowski writes that "Discourse is - in brief the text in context, not only fixed system of signs, but also the social context of its creation, dissemination and reception" (www 9).

The discourse around the exploitation of mineral resources is so varied that in principle we should talk about discourses. They are divided not by different operating technologies or even the nature of the raw material but rather by the importance they have in the culture of the region.

An example of such duality is the exploitation of coal deposits in Upper Silesia and Lublin Basin, or in Wałbrzych. The difficulties in closing unprofitable mines in the first of these places and the relative simplicity of closing the mines in Wałbrzych seem to be a source of regional culture, where the media and public opinion devote much more attention (and texts) to mining of coal in these regions, where such 
activity the supports the regional identity, local culture and also the world discourse. The discourse understood in such way has completely prosaic face. Closing the mines in places where mining activity is a part of the regional identity and represents a significant part of the regional discourse for political reasons is much more difficult than elsewhere. At the same time, trade unions block opening new mines in Lubelskie, following the current profits for the mine staff (DZIADUL \& GRZESZCZAK, 2015).

Discourse built around the mining of coal is not the only one. The discourse built around the exploitation of oil, natural gas and uranium are also very important from social and political point of view. Mineral resources - their production and consumption are the keystone of environmental discourses. The example of such discussion is the meeting entitled "Shale gas - the challenge for the democracy" which took place on 16th March 2013 in Warszawa (www 6). The very first question asked is: „how does shale gas extraction concern the values of a democratic country", later it is said that shale gas exploitations is Donald Tusk's obsession. The company that was to run potential exploitation is accused of lying. The participants of another debate, run by Polskie Radio, discuss the extraction of the shale gas within the context of the country safety (www 7).

The discourse "carries" social memory. According to Szacka discourse is: "collective memory, social memory - a set of images of the past, as well as all of all the characters and events of the past that are commemorated in a variety of ways; the meaning also covers there are various ways of such commemoration" (SZACKA, 2000, p. 52).

Szacka also writes that: "social memory has features such as the transmission of values and patterns of desired behavior, the legitimacy of authority, creating the sense of collective identity based on the awareness of a common past, the existence in time, ancestors, fate and symbols" (SZACKA, 2000, p. 53). Social memory is also visible in celebrating the anniversaries of Silesian Uprisings or in building the monuments for the heroes who fought in Silesia, as well as in preserving the traces of those fights, such as pillboxes (PIETRUCHA, 2006).

Thanks to the social memory - as Halbwachs writes - various groups in society are able at any time to rebuild their past (HALBWACHS, 2008, p. 422). Social memory is present wherever the exploitation of mineral deposits are. It is manifested, according to GOLKA (2008, p. 17), through the following functions:

1) it transmits knowledge concerning the past,
2) it passes cultural competence (including communication competence, ways of understanding certain symbols),

3) it shows patterns which are important from the point of view of the history of the group,

4) it passes values recognized by the group as important and therefore worthy of being fixed,

5 ) it provides information about the real or alleged (mythical) genesis and structure of the group,

6) it is a factor in co-creating group identity,

7) it is a factor specifying relationships between neighboring groups (including between the dominant group and dominated groups),

8) it expresses any ideologies (including political and social interests),

9) it could be a way of authority implementing

10 ) it is the impact factor for the future by laying out specific, relatively permanent trajectory of group history.

All this constitutes unique regional cultures, organizational or even national (e.g. Kuwait) focused on the extraction of mineral resources. Those are accompanied by the specific artifacts active mines and out-of-date post-mining objects, ruined or transformed into lifts, museums of shopping centers, myths connected with mining salt, as well as jargon, habits or economic resources. The examples of these may be the "Sztygarka” museum and shopping Centre Silesia City Center in Katowice. All those create the last of the enumerated phenomena, meaning social capital.

According to Lin, the capital is "the investment of the resources together with the expected profits from the market" (LIN, 2001). The source of social capital are social ties. Inclusive ties, directed inwards, allow to strengthen the excluded communities. They create the order that protects status quo. Inclusive ties create so called social inclusive capital (SIEROCIŃSKA, 2011, p. 74-75). They are therefore useful when one ought to save the feeling of belonging to the group . they appear wherever stopping the exploitation or technology transformation evoke changes that are unwelcome from the perspective of local community.

Exclusive ties are directed outwards, they connect varieties and allow to use external assets and shared information. They create social exclusive capital. Such capital is given when, for example, there are run the preparatory exploitation activities and the local communities compete to have it and the profits connected with it.

Social capital is a king of adhesive keeping the society whole, without which economic increase of human profiting cannot take place (PoGONOWSKA, 2004, p. 15-16). 
According to Dyduch (www 1), there are six factors of social capital. They are as follows: participation in networks, mutuality, trust, social norms, community and pro- activity.

Social capital is the knowledge based on social relations. It is connected with the trust organization members have towards each other, with the norms and the values (www 3). Summing up, the reflection concerning the notion of social capital is focused on the issues of cooperation, trust and of following social norms, as well as participation in social contact networks.

CYBULA \& SZCZEPAŃSKI (1997, p.128) claim that the social capital significantly dropped in Silesia district in the times of communism, when there took place "considerable weakening of the tradition to self-organize the community. That was mostly the consequence of the country and the political party policy, as they were opposed to any local initiatives that were difficult to control".

\section{Conclusion}

The presented sketch does not fully exploit the notions described in the title. Such issues as PIMBY, NIMBY and BANANA were consciously omitted as those which are widely described in the professional literature. Similarly, the notion of moral panic has also been discusses. The idea of symbolic violence deserves to be described more fully - especially in the context of the protests movements and the ways to deal with them. The notions that seem to be being neglected, especially in Polish scientific literature, are those connected with gender, understood as social sex following raw materials exploitation. The hereby discussion, as well as signaling the import ant scientific topics are to hope that the hereby article will be a toehold of further scientific examinations.

The enumerated issues have been but a small part of what is happening with the community in case of mineral resources exploitation. It is impossible to state explicitly of such exploitation is of positive or negative effects. However, it always is the important social change that requires scientific study.

\section{References}

Badera J. 2014. Problems of the social non-acceptance of mining projects with particular emphasis on the European Union - a literature review. Environ. \& SocioEcon. Stud., 2, 1: 27-34.

Badera J., Kocoń P. 2014. Local community opinions regarding the socio-environmental aspects of lignite surface mining: experiences from central Poland. Energy Policy, 66: 507-516.

Badera J., Kocoń P. 2015. Moral panic related to mineral development projects - examples from Poland. [has been accepted for publication in Resources Policy]

Bratnicki M., Kryś R., Stachowicz J. 1988. Kultura organizacyjna przedsiębiorstw. Stadium kształtowania procesu zarządzania. Ossolineum PWN, Wrocław.

Bourdieu P., Wacquant J. 2001. Zaproszenie do socjologii refleksyjnej. Ofic. Nauk., Warszawa.

Cybula A., Szczepański M.S. 1997. Kapitał społeczny a dostosowanie do zmian systemowych. Przypadek województwa katowickiego. [in:] Malikowski M. (ed.) Problemy społeczne $w$ okresie zmian systemowych $w$ Polsce. Mat. z konf. nauk., Mana, Rzeszów.

Golka M. 2008. Pamięć społeczna i jej implanty. SCHOLAR, Warszawa.

Grzeszak A., Dziadul A. 2015. Kto połamie sobie zęby na węglu. Krótki kurs czarnej magii. Polityka, 20 stycznia, $04 / 2015$.

Halbwachs M. 2008. Społeczne ramy pamięci. PWN, Warszawa.

Hofstede G. 2000. Kultury i organizacje. PWE, Warszawa.

Kostera M. 1996. Postmodernizm $w$ zarzqdzaniu. PWE, Warszawa.

Koźmiński A.K., Piotrowski W. ed. 1995. Zarządzanie: teoria i praktyka. PWE, Warszawa.

Lin N. 2001. Social Capital A Theory of Social Structure and Action. Cambridge Univ. Press, Cambridge.

Matczak P. 1996. Społeczne uwarunkowania w eliminacji syndromu NIMBY. [in:] Cichocki R. (ed.), Podmiotowość społeczności lokalnej. Media G.T, Poznań.

Nawrocki T. 2006. Trwanie i zmiana lokalnej społeczności górniczej na Górnym Śląsku: na przykładzie Murcek. Uniw. Śląski, Katowice.

Pietrucha D. 2006. Fortyfikacje Obszaru Warownego "Śląsk": historia, przewodnik. Pro Fortalicium, Bytom.

Pogonowska B. 2004. Kapitał społeczny - próba rekonstrukcji kategorii pojęciowej. (in:) Januszek H. (ed) Kapitał społeczny aspekty teoretyczne i praktyczne. Akad. Ekon., Poznań.

Schechner R. 2000. Przyszłość rytuału. Ofic. Wyd. Volumen, Warszawa.

Schein E. 1992. Organizational Culture and Leadership. 2nd ed. Jossey-Bass, San Francisco, CA.

Sierocińska K. 2011. Kapitał społeczny: definiowanie, pomiar i typy. Econ. Stud., 1 (LXVIII).

Szacka B. 2000. Pamięć społeczna. [in:] Encyklopedia Socjologii, t. 3, Ofic. Nauk.

Van Dijk T.A. (ed.) 2001. Dyskurs jako struktura i proces. PWN, Warszawa.

Wódz J., Wódz K. 2004. Czy nadciągają Ślązacy? [in:] Nijakowski L.M., (ed.) Nadciągają Ślązacy. Czy istnieje narodowość śląska? Scholar, Warszawa.

Wódz K. (ed.) 1993. „Swoi” i „obcy” na Górnym Śląsku. Z problematyki stosunków etnicznych, Śląsk, Katowice.

www 1 Dyduch W. Kapitał społeczny organizacji pożywką dla przedsiębiorczości i innowacyjności. http://www. zti.com.pl/instytut/pp/referaty/ref42_full.html za Bullen, P., Onyx J: Measuring Social Capital in Five Communities in NSW. Internet, http://www.mapl.com.au.

www 2 http://kghm.com/pl/o-nas/kultura-miedzi/tradycjegornicze.

www 3 http://mfiles.pl/pl/index.php /Kapita\%C5\%82_ spo $\%$ C5\%82eczny.

www 4 http://www.bajkowyzakatek.eu/2010/11/polskietradycje-barborka.html.

www 5 http://www.kopalnia.pl/o-kopalni/kopalnia-wczoraj-idzis/tradycje-gornicze. 
www 6 https://obywatelekontroluja.pl/debata- podczasseminarium-gaz-lupkowy-w-polsce-wyzwanie-dlademokracji/.

www 7 http://www.polskieradio.pl/13/53/Artykul/ 1073312, Debata-polityczna-Jedynki-bezpieczenstwo-energetycznePolski. www 8 Jar JK 2014 Górnicy z kopalni Kazimierz-Juliusz wygrali z rządem wszystko: pracę, mieszkania, kopalnię. Tylko węgla mało.

www 9 Nijakowski L.M: Analiza dyskursu na temat mniejszości narodowych i etnicznych $w$ polskich mediach, http://www.racjonalista.pl/kk.php/s,4820. 